\title{
Miedos medievales en tierras americanas: la circulación de una imagen posible de América a partir de la crónica de Diego de Ocaña*
}

\section{Medieval Fears in American Lands:}

\section{The Circulation of a Possible Image of America} from Diego de Ocaña's Chronicle

\author{
Silvina Andrea Mondragón \\ Departamento de Historia \\ Universidad Nacional del Centro de la Pcia. de Buenos Aires \\ Argentina \\ Correo: silvinamondragon@yahoo.com.ar
}

DOI 10.48102/hyg.vi54.293

ABSTRACT

From the chronicle of the trip that Fray Diego de Ocaña made between 1599 and 1605 throughout South America, I seek to analyze the description that the monk made of the different cultural spaces where he traveled for five years and that questioned his own mental representations. The objective is to trace the description of America and of the American made by Ocaña based on the ways the spaces were "made visible" and "assumed" by him, weighing his misunderstanding of the unknown and the meanings he gave to the observed. The final interest is to analyze the way in which the circulation and appropriation of material and immaterial symbols, which characters such as those displayed by Ocaña, ended up forming sui generis American identities, despite the geographical origin of the observers.

Key words: Mental Representations, Cultural Circulation, Atlantic History.

* Una primera versión de este trabajo fue presentada como ponencia en el xxiII Coloquio de Historia Canario Americana que se celebró entre el 8 y el 12 de octubre de 2018 en Casa de Colón, Las Palmas de Gran Canaria, España. 


\section{RESUMEN}

A partir de la crónica del viaje que realizó fray Diego de Ocaña, entre 1599 y 1605 a lo largo de América del Sur, pretendo abordar la descripción que el monje hizo de los diferentes espacios culturales que recorrió a lo largo de cinco años y que horadaron sus propias representaciones mentales. El objetivo de este artículo consiste entonces en rastrear la descripción que hizo Ocaña de América y lo americano, a partir de las formas en que fue "visibilizado" y "asumido" por él, sopesando su incomprensión de lo desconocido y los significados que otorgó a lo observado. El interés final consiste en analizar la forma en que la circulación y apropiación de símbolos materiales e inmateriales, que personajes como Ocaña desplegaron, terminaron por conformar unas identidades sui generis americanas, a despecho del origen geográfico de los observadores.

Palabras clave: representaciones mentales, circulación cultural, historia atlántica.

Artículo recibido: 22/09/20I9

Artículo aceptado: I9/10/20I9

\section{INTRODUCCIÓN}

$\mathrm{E}$ ntre 1599 y 1605 , el viaje que el fraile Diego de Ocańa hizo por algunas regiones recónditas de América del Sur quedó plasmado en las descripciones de lo que observaba y vivía. ${ }^{1}$ La subjetividad del relato, cargado de consideraciones emocionales y personales, invita a reflexionar en qué motivos tendría un fraile Jerónimo para dejar las comodidades del monasterio español en el que vivía y viajar por tierras sudamericanas en las postrimerías del siglo XVI.

Más allá de las cuestiones formales, que incluyen la obediencia a los mandatos de la Orden, ${ }^{2}$ es razonable suponer que moti-

\footnotetext{
${ }^{1}$ Una descripción de su estilo de escritura y el contexto de producción, en José Roso Díaz, "El fraile Jerónimo Diego de Ocańa. Un apunte sobre devoción mariana, arte y literatura en la América hispana del Barroco".

${ }^{2}$ El objetivo del viaje de Diego de Ocaña y del compañero con el que partió desde Sevilla, era fomentar la autoridad moral del monasterio de Guadalupe,
}

\section{4 / Silvina Andrea Mondragón}


vaciones de índole intimista y personal, alentaban el cruce del Atlántico. La travesía era un símbolo visible de otro intangible: un viaje hacia el alma y el espíritu que se iniciaba buscando aquietar las pasiones de la carne.

Esta búsqueda se beneficiaba de los rigores de las lejanías desconocidas ya que, como había supuesto Aristóteles, los actos épicos eran el corolario de las dificultades por las que atravesaban los héroes. ${ }^{3}$ De hecho, se asociaban con la valentía necesaria para enfrentar las vicisitudes y los miedos que provocaba la inmensidad de un mar plagado de peligros. En efecto, morir ahogado en el océano impedía el ritual cristiano de la muerte, poniendo en peligro la salvación del alma: como no se podía dar cristiana sepultura al cuerpo, peligraba la propia glorificación en estado de plenitud física, en la segunda venida de Cristo. ${ }^{4}$

recoger las donaciones que se hacían al culto a la virgen y también reglamentar el futuro envío de las remesas a España. No se trataba de un viaje fortuito, ya que "es necesario apuntar que el viaje de fray Martín de Posada y de fray Diego de Ocańa se da como consecuencia de una crisis económica en la que se encontraba el monasterio desde los años sesenta, debida principalmente a la disminución de las limosnas por la mala situación económica en la que estaba el país". Fray Diego de Ocaña, Viaje por el Nuevo Mundo. De Guadalupe a Potosi, 1599-1605, p. 15.

3 "Quietude, a state of inner stillness, was sought by many early modern missionaries as the stage from which truly to begin. Somewhat paradoxically to our lights, for many in the sixteenth and seventeenth centuries, this state of mind and spirit was not only to be found in quiet prayerful seclusion with their brothers or sisters at home [...] Aristotle had taught that difficulty was what most summoned people to heroic acts". Kenneth Mills, "Mission and Narrative in the Early Modern Spanish World. Diego de Ocaña’s Desert Passing”, p. 117.

4 "A finales del siglo XVI se pretendió obligar a los marineros a portar cédulas de confesión, mientras que algunas ordenanzas espańolas recomendaban que el capitán vigilara que su tripulación viviera 'Christianamente y en el temor de Dios'. El miedo era no poder alcanzar la gloria divina, pero también no poder ser enterrado una vez muerto. Esto constituía una verdadera desgracia, pues se creía que un cuerpo a la deriva no podría encontrarse para la resurrección general, por lo que las almas estaban condenadas a vagar, expresando sus lamentos en el silbido del viento y el graznido de las gaviotas". Vera Moya Sordo, "El miedo en el escenario del viaje atlántico ibérico, siglos XV-Xvı", p. 250. 
Por este tipo de determinaciones se debe ponderar en el análisis histórico la perspectiva subjetiva del monje que se expresa inexorablemente en la articulación misma del relato. Hace tiempo que la Historia cultural ha demostrado que sólo lo comunicado constituye el hecho social, por lo que la descripción de lo observado que Ocaña puso por escrito, lejos de tratarse de una manifestación personal es una construcción social, espacial y temporal: un relato histórico cargado de significados, en el que el narrador es un sujeto atravesado por su propia historicidad, ${ }^{5}$ y que el historiador ha de poder descifrar.

El análisis de determinados pasajes de la crónica que propongo en este trabajo, busca rastrear e identificar el espacio figurado que se forjó a partir de la conquista, entre españoles y americanos. ${ }^{6}$ Tendré entonces que abordar la retroalimentación entre las descripciones de lo ritual y de lo simbólico presente en el relato, sopesando la subjetividad de Ocaña y considerando la importancia que la fe y sus anclajes religiosos tenían en la representación mental del Nuevo Mundo que el monje estaba forjando. ${ }^{7}$

\footnotetext{
5 "Miradas no comunicadas, de una u otra manera, no pasan a formar parte del mundo social, pues se quedarían en el interior del individuo que las vive. Por lo que, al referirnos a 'miradas' no estamos pensando en su existencia psíquica, sino en su existencia social, esto es, en comunicaciones que expresan experiencias individuales". Alfonso Mendiola, "El giro historiográfico: la observación de observaciones del pasado", p. 183.

${ }^{6}$ Derivo esta clave analítica de Dominique Iogna Prat cuando sostiene que "El espacio deviene un elemento de definición explícita de lo social, quedando la pertenencia social mediatizada por la pertenencia espacial; las identidades sociales remiten cada vez más a los modos de inscripción espacial particular, definiendo de una manera nueva las relaciones entre los que ocupan un mismo espacio, los habitantes de un lugar, y las relaciones entre dominantes y dominados". Dominique Iogna Prat, La invención social de la Iglesia en la Edad Media, pp. 231-232. ${ }^{7} \mathrm{La}$ de los jerónimos es una orden española por excelencia. Asociados a la Corona, su cronista general la definió como "una religión natural de Espańa y de españoles, nacida, criada y sustentada dentro de sus términos, sin haber querido jamás traspasar sus lindes". José de Sigüenza, Historia de la Orden de los Jerónimos, p. 53. Sobre la presencia de jerónimos en América, véase Francisco Campos y Fernández de Sevilla, "La orden de san Jerónimo en Hispanoamérica: análisis político, religioso y socioeconómico de unas experiencias".
}

\section{6 / Silvina Andrea Mondragón}


Todavía en las postrimerías del siglo XVI, los relatos de viajeros eran respaldados por una aceitada tradición que hundía sus raíces en el mundo árabe del siglo x y que había demostrado en qué medida eran funcionales para sensibilizar en torno a lo desconocido y crear imágenes convincentes de la otredad. ${ }^{8}$ En cada uno de ellos, el autor buscaba generar empatía con el lector (posible viajero futuro), a quien confiaba los infortunios vividos y los extraños ritos presenciados.

Paul Zumthor ha señalado que en realidad, con cada escrito, se estaba trazando el itinerario de una santidad ya que "la memoria se proyecta en el espacio sagrado y el discurso mediante el cual desempeña una función de iniciación. Se trata de una función fuerte, que corresponde a uno de los rasgos específicos del cristianismo medieval, religión del espacio más que del tiempo".

Para el hombre bajomedieval, el espacio era todavía un favor concedido por Dios y, como tal, un símbolo del cristianismo. ${ }^{10}$ Esto determinaba la obligación de protegerlo y evangelizar a sus pobladores.

Para el historiador, las crónicas de viajes a Indias del siglo XvI cobran interés en tanto forman parte de un específico dispositivo argumental imperial que contribuyó con eficacia a legitimar determinadas categorías de valoración sensorial. Estas categorías fueron basales para la posterior construcción de nuevas identidades hispanoamericanas.

En este sentido, la valoración de las expresiones culturales de los nativos que Ocańa hizo, pone en evidencia la agudeza con que

8 "Desde el siglo $\mathrm{x}$, el mundo árabe identificaba (y a veces enseñaba) los relatos de viajes como un género literario autónomo, emparentado con la novela [...] en los países de la Cristiandad, textos más o menos comparables ejercieron sobre sus lectores o auditores una influencia nada despreciable, tanto por los hechos que revelaban como por la significación que revestían en la mentalidad colectiva”. Paul Zumthor, La medida del mundo. Representación del espacio en la Edad Media, p. 285.

${ }^{9}$ Ibidem, p. 287.

${ }^{10}$ Ibidem, p. 32. 
era interpelado por lo que observaba, ya que su relato ${ }^{11}$ espejea buena parte de sus símbolos culturales, ${ }^{12}$ anclados en una religiosidad bajomedieval en la que la atención a lo maravilloso y la dominancia de las emociones sobre el intelecto eran los componentes esenciales. ${ }^{13}$

A causa de este tipo de consideraciones puede mitigarse el dilema de base respecto de la existencia, o no, de una relativa homogeneidad cultural y material entre la amplia gama de espacios sociales y geográficos conectados por el Atlántico, ${ }^{14}$ si se considera

${ }^{11}$ Raymond Williams ha señalado en qué medida los productos y símbolos culturales son elementos necesarios en la configuración del hecho social. Raymond Williams, Sociología de la cultura, p. 13.

${ }^{12}$ En ciencias sociales, lo señalado es tributario de trabajos clásicos: Roger Chartier, El mundo como representación. Historia cultural: entre práctica y representación; Carlo Guinzburg, El queso y los gusanos. El cosmos según un molinero del siglo XVI; Robert Darnton, La gran matanza de gatos y otros episodios en la historia de la cultura francesa; Edward Thompson, Costumbres en común.

13 "En efecto, al ser empleados como pruebas del discurso biográfico, los documentos sólo muestran su cara manifiesta o luminosa; todos ellos tienen, sin embargo, al mismo tiempo, otra cara, una cara oculta, que está en lo obscuro y que los convierte necesariamente en indicios. $Y$ es que el carácter de indicio no le viene al documento de su precariedad, o de su fragmentariedad, de una insuficiencia cuantitativa suya, que le impida cumplir con el ideal de ser una prueba plena. Le viene simple y llanamente del hecho de ser una huella humana”. Bolívar Echeverría, Discurso crítico y filosofía de la cultura.

${ }^{14}$ La alternativa respecto de una "historia atlántica", propuesta en 1955 por Jacques Godechot y Robert Palmer, ha servido de inspiración para sucesivas generaciones de historiadores que han encontrado en este cambio de perspectiva, de escala y de concepción del tiempo, terreno fértil para volver a trabajar sobre cuestiones que en apariencia ya estaban agotadas. A la manera de Fernand Braudel y su emblemático El Mediterráneo, y el mundo mediterráneo en la época de Felipe II, diversas generaciones de historiadores se han interesado en poner a prueba la idea de si, en ambas márgenes de los enormes espacios de influencia del océano Atlántico, se desarrolló un ámbito geográfico específico, constitutivo de una verdadera y particular civilización. En estos términos se entiende que puede hablarse de una civilización común porque en ella se identifican ideas matrices compartidas; algunas que se remontan a la Antigüedad clásica y otras de surgimiento mucho más reciente. Esta amalgama, que mixtura en un mismo espacio y tiempo componentes judeocristianos, la ley romana y la razón griega, con nuevos valores de una sociedad libre e individualista, portadora de una nueva idea de poder legítimo, fue capaz de tutelar desde los espacios urbanos (se-

\section{8 / Silvina Andrea Mondragón}


la funcionalidad de las grandes redes de intercambio y de circulación de objetos, discursos y personas que se organizaron a partir del siglo XVI.

A partir de estos supuestos y teniendo en cuenta que la modernidad habría de ser concebida como "la forma histórica de totalización civilizatoria que comienza a prevalecer en la sociedad europea en el siglo XvI", ${ }^{15}$ se impone un análisis histórico crítico de la relación entre las ideas/representaciones mentales y el poder, entendido como "un aspecto de todas las relaciones entre las personas", ${ }^{16}$ que no obstante las trasciende para organizar y gestionar campos de acción en favor de los sectores hegemónicos. ${ }^{17}$

\section{Ocaña y EL ESPACio}

El marcado nomadismo de personajes como Diego de Ocańa que recorrió $35000 \mathrm{~km}$ en seis años, contribuyó a perfilar un sentido universalista del territorio que exploraban. ${ }^{18}$ Portador por exce-

des por excelencia de la burocracia, las decisiones y el aprovisionamiento) hasta los inmensos, hostiles y maravillosos espacios de frontera. Jacques Godechot y Robert Palmer, "El problema del Atlántico, del siglo xviII al xx", ponencia presentada en el Congreso de la Asociación Internacional de Ciencias Históricas, Roma, 1955. Una mirada superadora que consigue sintetizar medio siglo de discusión histórica, se puede encontrar a lo largo del trabajo de Serge Gruzinski. El autor sostiene que se debe ponderar una historia atlántica desde una mirada historiográfica ampliada, descartando de plano la mirada eurocéntrica. Desde esta perspectiva, el historiador debe exhumar las relaciones y los enlaces históricos que se dieron entre las sociedades, para poder explorar historias múltiples: ligadas, conectadas y comunicadas a partir del Atlántico.

${ }^{15}$ Bolívar Echeverría, La modernidad de lo barroco, p. 144.

${ }^{16}$ Eric Wolf ha resaltado la importancia de analizar la mutua influencia entre el mundo de las ideas (en tanto constructos culturales) y el poder, al demostrar que "tanto la cooperación como el conflicto invocan e implican juegos de poder en las relaciones humanas y las ideas son emblemas e instrumentos en estas interdependencias siempre cambiantes y cuestionadas". Eric Wolf, Figurar el poder. Ideologías de dominación y crisis, p. 18.

${ }^{17}$ Ibidem, p. 20.

${ }^{18}$ Zumthor, La medida, op. cit., p. 232. 
lencia del espíritu de cruzada, el discurso de los religiosos era, en esencia, consecuencia de la movilidad que los alentaba.

Ocańa era una voz que emanaba de los sectores dominantes y que intentaba entender y resignificar la realidad cultural y material que observaba, con el fin expreso de evangelizar a los nativos. Para ello recurría no sólo a las palabras: las imágenes de los principales símbolos del cristianismo que llevaba consigo, al igual que su probidad como pintor de la figura de la virgen de Guadalupe, fueron útiles para crear un sustrato de sentidos comunes asignados por los espańoles al espacio atlántico. El fraile era consciente de la importancia de sus dibujos y de los fines que perseguía al hacerlos: "Y así hice estas imágenes adonde había otras, porque las limosnas no se perdiesen y se diesen a otras y adonde no las había, como fuese en Potosí y en Chuquisaca, las hice para que fuesen mayores las limosnas y para que no se perdiese la memoria, y asi entiendo haber acertado".$^{19}$

Por este tipo de cuestiones, no importa tanto si la evangelización de los nativos resultó efectiva; más bien lo que interesa son las herramientas y los medios por los que los espańoles pudieron construir una hegemonía discursiva respecto de América y lo americano. En suma, el propósito es considerar lo escrito como un producto mediado por los sentidos del autor, pero también a los lectores como sujetos interpelados por aquellos sentidos.

Aunque no se trata de una crónica oficial, es decir no fue pedida ni confirmada por la Corona, respeta a cabalidad las instrucciones formalizadas en la Instrucción y memoria de las relaciones que se han de hacer para la descripción de las Indias, ordenada por Felipe II en 1573. Por esto es detallada con esmero la información que describe la fauna y la flora autóctonas, así como el clima o las viviendas de los aborígenes. Lo que la convierte en un relato único es que permite conocer a un personaje que vive y siente América en tanto se presenta como protagonista de una descripción en la que sus emociones son protagónicas.

${ }^{19}$ Ocańa, Viaje, op. cit., p. 307. Las cursivas son mías. 
Entiendo que toda la inabarcable construcción narrativa del XVI contribuyó a delimitar un espacio atlántico coherente y una nueva identidad, que combinó no sólo las imposiciones culturales de los dominadores, sino que se nutrió también de las resignificaciones de los constructos culturales de los dominados, aunque nunca llegaran a anularlos por completo. ${ }^{20}$

\section{UNA NOCHE APOCALÍPTICA EN LIMA}

A finales de diciembre de $1605,{ }^{21}$ Ocaña fue testigo de un hecho asombroso que lo hizo aseverar que "no he visto ni espero ver semejantes cosas como aquella noche pasaron". ${ }^{22}$ Un fraile franciscano $^{23}$ había predicado en la plaza principal de Lima un mensaje apocalíptico que auguraba a los limeños las más terribles consecuencias por sus pecados.

No parece tratarse de un sermón fuera de contexto; hacía pocos días las ciudades de Arica y Arequipa habían sufrido una inundación y un terremoto, respectivamente, por lo que es imaginable un estado de miedo general agudizado por los cataclismos naturales.

20 "Las representaciones colectivas son las matrices del mundo social que se presenta en dos niveles: el primero de ellos se observa en la construcción de identidades sociales como resultantes siempre de una relación forzada entre las representaciones impuestas por aquellos que poseen el poder de clasificar y designar la definición, y una segunda que considera la representación que cada grupo hace de sí mismo". Pablo Castro Hernández, "Monstruos, rarezas y maravillas en el Nuevo Mundo. Una lectura a la visión europea de los indios de la Patagonia y Tierra del Fuego mediante la cartografía de los siglos Xvı y xviı", p. 35. ${ }^{21}$ No hay certeza respecto de las fechas que se registran en la crónica (varían en un año), ya que Ocaña tomaba apuntes durante el viaje y sólo cuando se instaló de manera definitiva en Lima se dispuso a componer la redacción definitiva. Hay que calcular también el tiempo que le llevó componer los dibujos que en ella aparecen.

${ }^{22}$ Ocańa, Viaje, op. cit., p. 155.

${ }^{23}$ Se refiere al famoso fraile franciscano Francisco Solano, conocido por sus prédicas escatológicas en espacios públicos que suscitaban la fascinación y el temor del público. 
Al parecer, las iglesias permanecieron en alerta aquella noche, todos los conventos abrieron los sagrarios y encendieron cantidad de velas; de la misma manera, el Santísimo Sacramento estuvo descubierto. La escena era dantesca:

todos los frailes en las iglesias y clérigos arrimados por las paredes confesando a la gente, las cuales se confesaban algunos a voces $\mathrm{y}$ de dos en dos; aquella noche por las calles, muchos penitentes azotándose como noche de jueves santo. Hiciéronse muchas restituciones, diéronse muchas limosnas, muchos que estaban amancebados se casaron y hubo muchos desposorios, y toda la gente de la ciudad por las calles y en las iglesias todos llorando y dando gritos, todos gimiendo y suspirando, diciendo que aquella noche habían todos de ser hundidos. Y para mi fue aquella noche un retrato del día del Juicio y toda la ciudad haciendo verdaderas penitencias, pidiendo a Dios misericordia y haciendo los religiosos muchas plegarias. ${ }^{24}$

Ocaña sintió que no era posible significar por escrito lo que aquella noche sucedio. ${ }^{25}$ No encontró parámetros con los que describir lo vivido aunque los miedos ajenos lo hicieron expresar los propios: pensó que los penitentes que recorrían el campo esa madrugada, y que pudo ver desde la ermita que había montado en las afueras de Lima, eran en realidad ladrones que querían sacarle lo que tenía. En la crónica refiere que los penitentes podían en realidad ser ladrones encubiertos, tal y como solía suceder en España. ${ }^{26}$ Es claro que sus miedos habían sido configurados en Europa.

Este fragmento del relato de Ocaña, es especialmente útil para destacar la presencia del miedo como protagonista del relato.

Ya desde el año mil de la era cristiana podemos encontrar documentos que atestiguan la gradual formación de este entramado de símbolos atribuidos a lo terrorífico. Por caso, el monje francés

${ }^{24}$ Ocańa, Viaje, op. cit., pp. 155-156. Las cursivas son mías.

${ }^{25}$ Ibidem, p. 156.

${ }^{26}$ Ibidem, p. 156.

62 / Silvina Andrea Mondragón 
Raoul Glaber describió con detalle los terrores que provocaban a los hambrientos campesinos franceses del siglo XI fenómenos naturales como el paso de un cometa y las inundaciones que provocó. ${ }^{27}$ Nada diferente de la asociación que Ocańa hacía 600 años después en otro continente: la relación entre la furia de Dios y los desastres naturales tenían para entonces una larga historia compartida.

Este complejo de miedos populares, que a mi entender se consolidó en el occidente europeo poco a poco desde el primer milenio, necesitó de la Iglesia como fuente legítima de autoridad y de discernimiento del bien y del mal. Esto permitió, a su vez, que se fortaleciera como institución de poder y de control a partir de atribuirse una función de veedora y constructora de los parámetros éticos y morales del entramado social. De hecho, secuelas del milenarismo alentaban a personajes como Ocańa, que creían en la universalidad del mensaje evangélico al mismo tiempo que vivían enclaustrados en monasterios, esperando la segunda venida de Cristo. ${ }^{28}$

Ocaña era producto de un entramado sociocultural que había configurado a lo largo de los siglos un sistema de aprensiones al hambre, a la guerra, a las pestes y a los fenómenos incontrolables

${ }^{27} \mathrm{El}$ miedo a una naturaleza incontrolable y al hambre han gozado de un lugar protagónico en la Europa cristiana. Uno de los testimonios citados por Duby en su estudio sobre los terrores que suscitó el primer milenio de la era cristiana, es útil para demostrar lo que comento: "como si ya fuera usual comer carne humana, hubo alguien que la trajo toda cocida para venderla en el mercado de Tournus, como hubiese hecho con la carne de algún animal. Una vez apresado, no negó su vergonzoso crimen; acabó maniatado y entregado a las llamas. Otro fue de noche a desenterrar esa carne que habían sepultado en el suelo, la comió y fue quemado a su vez". Georges Duby, El año mil. Una interpretación diferente del milenarismo, p. 82.

28 "La tendencia milenarista, que no había desaparecido del todo, había dejado como herencia a la Iglesia el mito de la plenitud de los tiempos. Aún después de haber sido sacado de su marco original y de haber sido suavizado, este mito conservaba una intensa fuerza evocadora, pues enraizaba profundamente en la mentalidad cristiana”. Claude Carozi, Visiones apocalipticas en la Edad Media. El fin del mundo y la salvación del alma, p. 174. 
de la naturaleza de tal envergadura, que había penetrado muy profundo en las cosmogonías de los sujetos. También era el fraile de una Iglesia que, al menos en Castilla, no había podido contener a los espíritus temerosos de la baja Edad Media. ${ }^{29}$

En América, el fraile encontró los rastros palpables de sus miedos. La relación entre los hombres, la naturaleza, el diablo y Dios, aquí parecía más expuesta. Lo sobrenatural y la superchería estaban, en la mente de Ocańa, asociados con el mundo rural. Su estupor frente a los indígenas que exhibían sus cuerpos semidesnudos sin vergüenza en un territorio vastísimo, quedó registrado en su crónica.

La vista y el olfato deben de haber guiado el registro. A lo largo del relato, la vista se transforma en el sentido que rige la percepción de la realidad. Son muchas las ocasiones en las que lo que ve, termina definiendo lo que siente: vista y miedo van de la mano. ${ }^{30}$ En este aspecto, Ocańa no parece escapar a las generales de la ley: los hombres instruidos del siglo XVI, según Robert Muchembled, desconfiaron de los cuerpos y de los sentidos por entender que eran lo más bajo de la condición humana. Permitían el ingreso del pecado y, por tanto, de los demonios. Pero también concibieron el control de la gestualidad corporal como un símbolo de las buenas costumbres cristianas; formas púdicas de comportamiento público que en las impresiones de Ocaña distaban demasiado de las de los nativos. ${ }^{31}$

${ }^{29}$ Silvina Mondragón, “Entre Dios y la comunidad. Prácticas y percepciones campesinas en torno a la Iglesia y a la monarquía. Castilla siglos XIV al XVI".

30 "Hoy los historiadores ya casi no aceptan el criterio de Lucien Febvre o de Robert Mandrou, quienes establecen una jerarquía dominada por el oído y seguida por el tacto, donde la vista tiene un rol secundario y el olfato y el gusto se evocan de una manera muy vaga, porque la gente de la época les asignaba más importancia que nosotros”. Robert Muchembled, Historia del diablo. Siglos $X I I-X X$, p. 118.

31 “ $[\mathrm{H}]$ ubo algo esencial que se modificó en la civilización europea de los siglos XVI y XVII [...] los occidentales instruidos experimentaron una doble influencia que transformó lentamente su escala de percepción. La primera influencia provenía de un movimiento moral y religioso de desprecio hacia los sentidos,

\section{4 / Silvina Andrea Mondragón}


La descripción de las riquezas naturales del Nuevo Mundo da cuenta de la extrañeza y fascinación del fraile que, frente a lo que va descubriendo, no puede dejar de observar y registrar a partir de patrones mentales de un religioso castellano del siglo xvi. Su relato trasunta la forma en que él mismo se maravillaba y asombraba ante la exuberancia que lo rodeaba, nutriendo de contenido lo que sostiene Stephen Greenblatt cuando asegura que, en este tipo de personajes, se ponen en juego lógicas medievales y modernas, alimentando una retórica que justificaba la conquista desde el encuentro con lo maravilloso y lo exótico. ${ }^{32}$

En esencia, el poder de la maravilla permitía el reclamo de posesión territorial que motivaba las intenciones de los conquistadores. Fray Diego de Ocaña no es ajeno a estos supuestos ya que en varios pasajes de su crónica se puede percibir tanto el asombro

porque estos eran las puertas de entrada al pecado [...] por otra parte, la civilización de las costumbres enseñaba en lo sucesivo a comportarse con decencia y modestia y a evitar tanto los gestos brutales como las manifestaciones corporales intempestivas". Ibidem, pp. 118-119.

${ }^{32}$ Greenblatt se pregunta por qué Colón reclamó para sí (y para la Corona de Castilla en consecuencia) territorios desconocidos. La llegada a América significó para los europeos algo distinto del encuentro con otras culturas cercanas como los mongoles y los viajes relatados por Marco Polo. La distancia del viaje, el tiempo transcurrido entre la partida y la llegada, el total desconocimiento de la tierra por parte de los europeos y la ignorancia absoluta de las culturas nativas, su lenguaje, sus organizaciones sociopolíticas y creencias marcaron una diferencia crucial. La formalidad del acto de toma de posesión es, entonces, algo muy importante a la hora de analizar la llegada. El acto lingüístico que implica declarar, atestiguar y registrar el acontecimiento señala que Colón no es sólo el intermediario a través del cual la Corona puede reclamar posesión: también lleva a cabo el ritual de posesión en su propio nombre y en nombre de sus descendientes. Desde un formalismo cerrado subyacente al acto, Colón impide la intervención de aquellos que puedan reclamar en su contra; es decir, los nativos están ausentes en este asunto. Sobre todo por su incapacidad de comprender lo que Colón hacía debido a la inconmensurabilidad de las culturas. La toma de posesión enfrente de los mismos posesores llevó a posiciones encontradas entre juristas y teólogos. Stephen Greenblatt, Maravillosas posesiones. El asombro ante el Nuevo Mundo, p. 119. 
que le provocaban las formas de vida de los nativos como la imperiosa necesidad que sentía de evangelizarlos. Pero también la descripción densa que hace de lo que observa, es claro que está dedicada a unos lectores que no pueden hacerse la idea de otro, tan otro, sin que medien símbolos ficcionales en el relato. ${ }^{33}$

De hecho, la escena americana que creó este "mito de origen" generó un imaginario en los conquistadores en el que confluyeron visiones utópicas de la naturaleza y la asociación de lo salvaje y lo maléfico con lo indígena. ${ }^{34}$ Por caso, la descripción que Ocaña hizo de la ciudad de Cartagena es un claro ejemplo de este tipo de representaciones. Sobre todo, cuando asoció la enfermedad a la desnudez de los nativos: "y como están desnudos y cogen viento, vive la gente muy enferma; y andan, ansí aquí como en Portobelo y Panamá, muy descoloridas las personas". ${ }^{35}$

El registro discursivo de los españoles se asentaba tanto en la "maravilla" del descubrimiento como en la sobrenaturalidad del lugar, lo que fue utilizado como estrategia retórica en los relatos para legitimar la conquista.

En el mismo sentido, la descripción de las mujeres indígenas estaba plagada de símbolos religiosos propios de la modernidad temprana. Estas mujeres eran asimiladas, en la crónica, a demonios, brujas o cerdos, con toda la implicancia negativa que esto presuponía en un momento histórico en el que la violencia judicial en contra de la mujer se estaba agudizando. ${ }^{36}$

33 "Cada autor, cada viajero construye su objeto en virtud de su cultura, de su experiencia, de las circunstancias de su vida [...] todos estos autores desean evidentemente ser leídos, y la opinión que se hacen de su público interfiere con sus deseos: el problema del público hasta el siglo XviII es la dificultad que tiene para concebir la alteridad, salvo como una ficción". Zumthor, La medida, op. cit., p. 293.

${ }^{34}$ Castro Hernández, "Monstruos, rarezas...", op. cit., p. 34.

${ }^{35}$ Ocaña, Viaje, op. cit., p. 82.

${ }^{36}$ Sobre violencia judicial en contra de las mujeres en la Modernidad temprana, Fabián Campagne (ed.), Poder y religión en el Mundo Moderno. La cultura como escenario del conflicto en la Europa de los siglos XV a XVIII. 
[Y] el cabello negro y suelto y ellas morenas y tostadas del sol, no parecen por aquellos arenales sino demonios y brujas, Ellas no se lavan sino cuando van a la mar, que de ordinario está muy cerca de los pueblos en todos estos llanos. Y tienen tanta costumbre de lavarse en la mar, que la india acabada de parir se lava y a la criatura también; y desde que nacen se crían con esto, y con todo eso son puercas porque si no es cuando se ven junto a la mar, no se lavan. Y en casa aunque tienen las manos y las caras puercas, nunca se las lavan. ${ }^{37}$

El fraile las diferenciaba de las féminas criollas que le resultaban "muy hermosas, de buenas teces de rostros y buenas manos y cabellos y buenos vestidos y aderezos, se tocan y componen muy bien, particularmente las criollas que son muy graciosas y desenfadadas". 38

En la misma descripción sociológica que hacía de Lima, Ocaña asumía como un dato normal de la realidad la existencia de la prostitución, a la que justificaba dada la carencia económica de algunas limeñas: "Hay como en Castilla en las ciudades grandes, de bueno y de malo; la mucha necesidad que en algunas mujeres hay y la sobre que otras tienen es causa de que haya alguna libertad en mujeres, como en los demás pueblos de indios que es ordinario". ${ }^{39}$ Es evidente que en su escala de acciones pecaminosas la prostitución era asumida como un mal necesario; en cambio, la brujería debía ser perseguida, condenada y exterminada. ${ }^{40}$

${ }^{37}$ Ocaña, Viaje, op. cit., p. 114. Las cursivas son mías.

${ }^{38}$ Ibidem, p. 150.

${ }^{39}$ Idem.

40 "Estrechamente sometido a la voluntad divina, el imperio del diablo sobre el ser humano era transitorio, salvo para las brujas y los hechiceros a quienes se hacía necesario quemar como miembros corrompidos de la Iglesia. En realidad, la verdadera novedad de los tratados de demonología consistía en la invención de una figura de lo extremo, encarnada por cada miembro de la secta satánica, cuyo cuerpo se encontraba constantemente invadido por el demonio y llevaba su marca. Aquello que se les reprochaba no era únicamente el hecho de sostener una doctrina herética, sino de aceptar esa invasión permanente que invertía el 
De hecho, el proceso de interiorización del mal, y por ende la creencia en la brujería, las brujas y la consecuente necesidad de exterminarla, está asociado de modo nodal a la fascinación que lo maravilloso provocaba. Esto tiene una manifestación evidente en la aparición de lo fantástico como eje particular de las crónicas de viajeros. Por ello, la imagen monstruosa con la que el fraile describe a los nativos se confunde con lo mítico, lo sobrenatural y la extrañeza frente a lo distinto. Incluso cuando combaten junto a los europeos, Ocańa presupone que lo hacen sólo por aplacar su sed de sangre: "Sirven solamente cuando hay guerras de ayudar a los españoles, y esto sin que los llamen, sino que ellos se convidan por solo el vicio que tienen de matar y comer a los que matan, sin perdonar a ninguno". ${ }^{41}$

Como he señalado, la persistencia de las representaciones mentales propias del bajo medioevo continuaron condicionando los relatos de los viajeros en tierras americanas a lo largo de todo el siglo XVI. El temor al diablo y su capacidad infinita para infligir dolor y dependencia del mal, fueron parte constitutiva de las nuevas representaciones mentales que se generaban y alimentaban en la medida en que los españoles avanzaban en el control y conocimiento de las vastas extensiones del territorio americano.

Un caso paradigmático de la crónica de Ocaña es la descripción de un acto inquisitorial en la plaza de Lima, del que fue testigo ocular en 1605. Es interesante la composición sociológica de la capital del virreinato que este acto le permite a Ocaña retratar: asisten los agentes del gobierno, virrey y oidores; la Universidad; los dos cabildos (regular y seglar), y todas las órdenes. Es claro que un evento religioso presuponía la asistencia del pueblo

plan de Dios en el interior mismo de su envoltura carnal". Muchembled, Historia del diablo, op. cit., p. 117.

${ }^{41}$ Se trata de la caracterización de algunos de los pueblos que habitaban en la zona comprendida entre Buenos Aires y Santiago del Paraguay; se refiere en específico a los guaicuros y a los guatatares. Ocańa, Viaje, op. cit., p. 207. 
y de las autoridades. La imagen que ofrece el monje recuerda la composición orgánica de los municipios castellanos de la época.

Antes que los condenados y los quemados, todos judíos portugueses, lo que le llama la atención del fraile es la solemnidad majestuosa con que se celebra el acto. La descripción enfatiza el carácter público y colectivo del suceso porque, de acuerdo con su testimonio, la ciudad entera estaba involucrada en lo que se representaba como un festejo popular. De hecho, a Ocaña le pareció llamativo que para el día acordado se construyera un teatro a fin de que los habitantes de la ciudad no sólo presenciaran el acto sino que estuvieran cómodamente sentados. También se levantó un cadalso alto, con el propósito de que todos pudieran ver y participar en calidad de testigos del ritual.

La Iglesia en América participó con diligencia de la conquista territorial aglutinando a los pobladores en núcleos que se organizaban a partir de una planificación y/o encuadre urbano en el que lo religioso tenía una presencia destacada. Desde la iglesia ubicada en un predio central, hasta los monasterios de cada orden que inundan con cruces el paisaje o los cementerios que recordaban la finitud de la existencia y la importancia del cuidado del alma, la morfología arquitectónica de cada villa le recordaba a los nativos que eran parte de una sociedad cristiana. En algún sentido, la Iglesia se mimetizaba con la ciudad ya que era dadora de significados: la pertenencia a la comunidad de vecinos siempre estaba mediada por lo religioso que era el garante final del control del espacio público. ${ }^{42}$

Por este tipo de cuestiones, cuando llegó el momento de sentenciar a las mujeres acusadas de hacer trabajos de hechicería, Ocaña constata que su proceso se llevó a cabo en privado: el carácter público que hasta recién veíamos en el proceso a los judíos, se evapora con rapidez:

42 " [L]a ciudad se convierte, mimetizándose con la Iglesia, en la estructura portadora de pertenencia a la comunidad, una metáfora de la sociedad cristiana: es el cuerpo que reúne todas las funciones necesarias para la vida según el Cristo revisitado por la tradición eclesial". Prat, La invención social, op. cit., p. 187. 
Hay también por acá muchas hechiceras, particularmente indias y negras, que engañan con sus embustes a otras mujeres que fácilmente y de ligero se creen dellas, y se tuvo por buen orden no sacallas al acto a estas mujeres, sino allá en la capilla las penitenciaron, porque cuando les leen los procesos aprenden otras aquellos embustes y por esto no las sacaron en público ni las sacarán ya mas. ${ }^{43}$

Todavía en el siglo xvi, el diablo de los europeos era capaz de ingresar en un cuerpo humano para sodomizarlo, tiranizarlo o usarlo como agente de sus planes. Sin embargo, lo que hacía en especial susceptibles a las mujeres de caer bajo su órbita, era la primigenia maldición divina. Dios había denigrado la relación entre Eva y sus congéneres con Satanás por la eternidad de los tiempos cuando determinó el vínculo: "y enemistad pondré entre ti y la mujer, y entre tu simiente y su simiente; ella te herirá la cabeza, y tú le herirás el calcañar". ${ }^{44}$

De hecho, en pleno siglo Xvi se dieron a conocer algunos casos de hermanas poseídas. Tal es el caso de Jeanne Fery, quien entre 1584 y 1585 fue liberada, en el convento de Mons de la actual Bélgica, de un pacto de sangre que ella había sellado con el demonio. ${ }^{45}$ Este tipo de sucesos ponían a la Iglesia en alerta: no sólo el diablo trataba con brujas campesinas analfabetas, al parecer también podía inmiscuirse en el cuerpo de las religiosas.

Tal vez debido al conocimiento de este tipo de hechos, personajes católicos en tierras americanas agudizaron su poder de observación para detectar cualquier atisbo de acción demoníaca. Es claro que los nativos eran el caldo de cultivo: sin instrucción cristiana, carecían de los rudimentos básicos para enfrentar al diablo.

${ }^{43}$ Ocaña, Viaje, op. cit., p. 154.

${ }^{44}$ Génesis 3:15, Biblia del Oso, 1569. Versión/traducción de Casiodoro de Reina.

45 "Los casos importantes de posesión en los conventos fueron numerosos, sobre todo en la primera mitad del siglo XVII, sin llegar a ser por eso comunes, ni siquiera frecuentes". Muchembled, Historia del diablo, op. cit., p. 173. 
La contracara del fenómeno es que este tipo de presupuestos jerarquizaron como necesaria la presencia de frailes evangelizadores en el Nuevo Mundo. Eran ellos los que a la par de los conquistadores, contribuían con una apropiación simbólica del territorio a través de sus prédicas y escritos, conscientes tal vez de que para sus lectores sería difícil creer que existía en la realidad lo que ellos describían.

La descripción de los indios que Ocaña encuentra en Paraguay es una prueba de esto. En su relato, la caracterización de los nativos americanos siempre está asociada a lo demoníaco, a la fealdad y lo bestial: "pocos indios por los campos, desnudos como sus madres los parieron, ansí mujeres como hombres, y todos embijados [pintados con bija o bermellón] y feos, que no parecen sino diablos". ${ }^{46}$ Lo mismo sucede en ocasión de advertir a sus coterráneos las suertes que pueden sufrir si caen en sus manos:

Hay otras naciones tan bestiales en sus costumbres, que por curiosidad no se pueden dejar de decir aunque de suyo no son honestas, por ser costumbres entre ellos muy usadas y en muchas partes y tierras. Una es, que se llaman charrúas, que cuando cautivan a algunos españoles, los llevan a sus casas; y estos indios son muy feroces y valientes; y pelean con unas bolas atadas en unas cuerdas de nervios de guanacos y de avestruz, que dan con un caballo en tierra; y estas bolas son de piedra. ${ }^{47}$

Como último ejemplo, la descripción de los calchaquíes en la que aparece la máxima expresión de su estupor cristiano:

Hay otra nación que se llaman calchaquíes. Son muy valientes. Estos comen carne humana todas las veces que la alcanzan, y son muy caribíes. Y los muertos no los entierran, sino se los comen; y no solamente los que matan en guerra, sino sus mesmos hijos

\footnotetext{
${ }^{46}$ Ocaña, Viaje, op. cit., pp. 443.

${ }^{47}$ Ocańa, Viaje, op. cit., pp. 208, fols. 126.
} 
cuando mueren, diciendo que lo que ellos parieron no se tiene que enterrar sino volver a sus vientres. ${ }^{48}$

El semblante monstruoso de los indios se funde en el relato con lo fabuloso, lo prodigioso y la extrañeza frente a lo distinto. Es probable que lo real y lo irreal se confundan de forma tal que Europa termine de definirse a través de América a lo largo del siglo XVI. ${ }^{49}$

Esta clave analítica es la que creo que mejor explica el enojo del fraile cuando, en el interior de una iglesia en Paraguay, encuentra nativos desnudos sirviendo la mesa de los españoles. La descripción de la escena no carece de belleza: entre la furia de Ocaña y la risa de los presentes, queda al descubierto el encuentro cultural, profundo y dramático, entre dos mundos:

Y fuimos a la iglesia, la cual estaba llena de indios y indias, todos desnudos en cueros, y tan grandotes ellos y tan feos y tan deshonestos, que me causo grandísimo enfado, porque no traen cosa ninguna en las partes vergonzosas sino todo al aire. Y lo que mas me enfadaba era cuando servían la mesa, que se sirven dellos los espańoles, cuando llegaban con tanta deshonestidad a quitar alguna cosa de la mesa; y las mujeres están ya tan hechas a vellos ansí las espańolas, que no se les da nada y se reían mucho de lo que yo me enfadaba. ${ }^{50}$

Al igual que la palabra, la destreza que Ocaña tenía para el dibujo sirvió para acentuar la descripción negativa de los nativos. Por ejemplo, hizo pinturas en las que detallaba la vestimenta de

${ }^{48}$ Ibidem, pp. 209, fol. 128v.

49 "Las imágenes se tornan una herramienta esencial para comprender la diferencia y la propia identidad, permitiendo abrirse a nuevas perspectivas y espacios que establecen miradas distintas de la otredad, la cual ya no solo se vislumbra con los miedos y temores legados de las representaciones de su mundo, sino que reflejan una posibilidad de encuentro con las rarezas, extrańezas y exotismo de las nuevas tierras que definen un cruce cultural entre la imaginación y la realidad". Castro Hernández, "Monstruos, rarezas...”, op. cit., p. 35.

${ }^{50}$ Ocaña, Viaje, op. cit., p. 194.

\section{2 / Silvina Andrea Mondragón}


guerra de los indios en la gobernación de Chile. Es también en Chile donde queda impresionado por los indios araucanos a los que descubre no sólo con palabras sino con esmerados dibujos que muestran cuánto más corpulentos y fornidos eran que los demás. Para dar cuenta de las valiosas capacidades guerreras de estos indios, los individualizó en el relato, nombrándolos: así Lautaro, Caupolicán o Anganamón se parecen más a demonios que a seres humanos en las palabras de Ocańa. También relató con espanto el ataque que en Valdivia sufrieron los españoles, así como el rapto de mujeres y nińos cristianos en diversos poblados como los de Angol, Chillán y Villa Rica. ${ }^{51}$

Analizando los dibujos y las imágenes que el relato invita a fijar mentalmente, se puede seguir el hilo de Ariadna que lleva hasta los límites de la capacidad de observación y descripción de lo que los españoles encontraron en América. Incapaces de comprender la otredad y sin palabras que pudieran describir lo que veían, atinaron a definir por la negativa un mundo que no comprendían. ${ }^{52}$

También atinaron a recrear en el Nuevo Mundo las imágenes que les eran familiares. Pintar o dibujar es una toma de posición: se decide qué representar ya que se selecciona el objeto entre un sinfín de imágenes mentales allí ancladas a través de la experiencia del dibujante de determinados patrones socioculturales. Lo representado es, así, un símbolo cultural anclado espacialmente, que se encuentra allí en consonancia con el interés del pintor. Las réplicas que Ocaña pintó de la virgen de Guadalupe tenían una función evangelizadora clara: buscaban inspirar fe y ayudar a los indios a asumir una religión que era al mismo tiempo salví-

\footnotetext{
${ }^{51} \mathrm{Al}$ parecer, el mismo Ocańa sufrió un ataque de los indios cuando pretendió llevarse la limosna obtenida en el lugar.

52 "[L]a relación entre la experiencia y la sabiduría está empezando a cambiar. El discurso del viajero se basará de forma cada vez más explícita, en el postulado de la racionalidad de la naturaleza, de su reductibilidad a las categorías del lenguaje". Zumthor, La medida, op. cit., p. 295.
} 
fica y sacrificial. ${ }^{53}$ Sus altos niveles de abstracción debían volverse accesibles por intermediación de los monjes evangelizadores que recorrían América tratando de explicar lo esencial de un dios trinitario que se había vuelto hombre para la salvación del alma y cuyo cuerpo era devorado, vez tras vez, en cada misa.

De la mano de personajes como Ocańa, el culto guadalupano se consolidó en el Nuevo Mundo y se hizo cada vez más intenso y extendido en el espacio. La Iglesia católica gozó en América de la tenaz acción evangelizadora de monjes que crearon y propagaron una ritualidad religiosa efectiva que, con el correr del tiempo, se convirtió en un componente esencial de la vida cotidiana.

En su pluma, los relatos de los milagros de la virgen eran igual de sobrenaturales que los registros de las curaciones o los trabajos de las brujas nativas, pero como él buscaba imponer una cosmovisión cristiana a los nativos, con soltura denostaba las fuerzas metafísicas que asistían a las indias y validaba las que sostenían a los españoles. ${ }^{54}$

En un territorio desconocido, las imágenes que alguien como Ocaña incorporaba en una crónica adquirían un valor cultural clave en función de las creencias y sistemas de representaciones de la gente de su tierra. Un pacto no escrito acordaba que el dibujo servía para acceder a una representación de la otredad, aunque no estuviera obligada a ser real: de hecho, la representación del indígena de América que circula por Europa durante todo el siglo XVI presenta una fórmula iconográfica dual, es decir, fantástica y

${ }^{53}$ A lo largo del viaje, Ocańa pintó seis veces la imagen de la Guadalupe en distintas ciudades: Panamá, Lima, Potosí, Chuquisaca, Cuzco y valle del Ica. Ocańa, Viaje, op. cit., pp. 143, 229, 313, 467, 497.

54 "El relato milagroso constituye, pues, una fuente susceptible de ser interrogada, siempre que se le reconozca su singularidad. Esta singularidad implica reconocer que estamos en presencia de una elaboración doctrinal, que al plasmar por escrito un acontecimiento lo está creando y fijando en la memoria colectiva, convirtiendo en recuerdo algo que no es experimentado por la mayoría de quienes participan de ese recuerdo, es decir, de ese colectivo religioso". Gerardo Rodríguez, Frontera, cautiverio y devoción mariana, pp. 253-254. 
real a la vez, formando el famoso par de opuestos del buen salvaje frente al caníbal fiero y sanguinario.

Esta identidad ambigua que los viajeros creaban de los indígenas refleja un espacio en el cual los europeos depositaron una mirada determinada de la otredad, moldeada a partir de lo negativo, lo peligroso y lo no confiable.

Es evidente que el complejo de miedos construidos a lo largo de los siglos en Europa occidental se había trasladado al Nuevo Mundo. América era un territorio nuevo y desconocido donde confluían miedos con utopías y maravillas naturales que permitieron el nacimiento de un nuevo articulado de códigos, nociones y símbolos que con el tiempo propiciaron nuevas redes culturales que pusieron en contacto ambas márgenes del océano. ${ }^{55}$

\section{Conclusiones}

En resumen: el mundo americano fue sujeto de un proceso de construcción visual por parte de viajeros exploradores españoles. Por un lado, las imágenes que se forjaron de la otredad revelan diversos símbolos de la cultura observada, y por otro, esta misma distancia cultural servía para espejear y reforzar los lazos de una identidad que se pretendía europea. Estas construcciones identitarias, siempre han sido resultado de una relación de poder por medio de las cuales los dominados se han autoarrogado el poder de clasificar y cosificar al otro.

\footnotetext{
${ }^{55} \mathrm{Al}$ respecto, es interesante una propuesta de Zumthor que vincula los relatos de viajeros, la conquista de América y Utopía de Moro, para dar con lo que caracterizaba al lector del siglo xvi: "más que cualquier otro mensaje, el lector del siglo Xvi había percibido en Tomás Moro el desasosiego de la generación que 'descubrió América. La utopía es una abolición de la realidad intolerable de esta apertura sobre algo que parece ser el vacío. Cierra el espacio, para organizarlo en y para el texto: es decir, el relato lo engendra como espacio de representación en el que se encarnan y se anulan las contradicciones vividas; en el que se podría restañar el vértigo de lo que queda por hacer para sobrevivir en un mundo que ha perdido todo sentido de la medida”. Zumthor, La medida, op. cit., pp. 300-301.
} 
Lo que encontraron en América los europeos se diferenciaba demasiado de lo que conocían. El énfasis puesto por los cronistas de Indias en lo maravilloso tiene relación con la fascinación que ejerce la posibilidad de poseer lo lejano y lo extraño. La distancia cultural con la "otredad" se fundaba en la exageración de unos sujetos tan marcadamente "otros", que en realidad servían para reforzar los límites de la propia identidad.

Tantas veces sintieron que se quedaban sin palabras que pudieran reflejar lo que veían y lo que sentían, que necesitaron dibujar para poder dar fe de lo que observaban. Cronistas como Ocańa son personajes en tránsito entre lo medieval y lo moderno.

Lo que contaron de América, sirvió para argumentar, justificar y legitimar la presencia española en América.

Desde entonces, América, en tanto espacio físico, definió el hecho social: se generaron múltiples identidades a partir de la presencia de los europeos en los nuevos territorios de la Corona.

Pero como señalé al principio de este trabajo, Ocaña también importa en tanto individuo. Lo que lo motivó a cruzar el Atlántico y aventurarse en las lejanas tierras de América del Sur, es suficiente estímulo para reflexionar en torno al surgimiento del moderno individualismo. ¿Era un fraile que observaba el Nuevo Mundo con anteojos medievales o era un hombre que miraba desde un esquema de valores construido por él mismo?

Del mismo modo que no existió un paralelismo esquemático entre el despliegue de la moderna racionalidad y el fin de la Edad Media, no debiera esperarse un proceso homogéneo en el que los esquemas tradicionales de funcionamiento de las sociedades bajomedievales dejasen de existir para dar lugar a una sociedad de individuos. Todavía a finales del siglo xvi Diego de Ocaña era un habitante de los dos mundos. Como señala Van Dulmen: "numerosos 'individualistas' de la Modernidad Temprana solo podían desarrollar su vida en un mundo de convenciones y bajo la protección de la tradición". ${ }^{56}$ 鲥

${ }^{56}$ Richard Van Dulmen, El descubrimiento del individuo: 1500-1800, p. 11. 


\section{Bibliografía}

Campagne, Fabián (ed.). Poder y religión en el Mundo Moderno. La cultura como escenario del conflicto en la Europa de los siglos XV a XVIII, Buenos Aires, Biblos, 2014.

Campos y Fernández de Sevilla, Francisco. "La orden de san Jerónimo en Hispanoamérica: análisis político, religioso y socioeconómico de unas experiencias", Studia Monástica, vol. 2, núm. 30, 1988, pp. 305-338.

Carozi, Claude. Visiones apocalipticas en la Edad Media. El fin del mundo y la salvación del alma, Madrid, Siglo xxi de España editores, 1999.

Castro Hernández, Pablo. "Monstruos, rarezas y maravillas en el Nuevo Mundo. Una lectura a la visión europea de los indios de la Patagonia y Tierra del Fuego mediante la cartografía de los siglos XVI y XVII", Revista Sans Soleil. Estudios de la Imagen, núm. 4, 2012, pp. 30-52.

Cro, Stelio. "Los cronistas primitivos de Indias y la cuestión de los antiguos y modernos", en Sebastian Neumeister (coord.), Actas del IX Congreso de la Asociación Internacional de Hispanistas, Madrid, Vervuert Iberoamericana, 1989, vol. 1, pp. 415-424.

Duby, Georges. El año mil. Una interpretación diferente del milenarismo, Barcelona, Gedisa, 2000 (1967).

Echeverría, Bolívar. Discurso crítico y filosofía de la cultura, bajo una licencia Creavite Commons 2.5: Atribucion-NoComercial-SinDerivadas.

- La modernidad de lo barroco, México, Era, 1998.

Gómez, Alejandro y Federica Morelli. "La nueva historia atlántica: un asunto de escalas", Nuevo Mundo Mundos Nuevos, Bibliographies, 2006, págs. 1-11. En línea.

Greenblatt, Stephan. Maravillosas posesiones. El asombro ante el Nuevo Mundo, Barcelona, Marbot, 2008.

Iogna Prat, Dominique. La invención social de la Iglesia en la Edad Media, Buenos Aires, Miño y Dávila, 2016.

Lucena Giraldo, Manuel. "La historia atlántica y la fundación del Nuevo Mundo”, Anuario de Estudios Atlánticos, núm. 56, 2010, pp. 39-59.

Mendiola, Alfonso. "El giro historiográfico: la observación de observaciones del pasado", Historia y Grafía, núm. 15, julio- diciembre 2000, pp. 181-208.

Mills, Kenneth. "Mission and Narrative in the Early Modern Spanish World. Diego de Ocaña's Desert Passing”, en Andrea Sterk y Nina Caputo (eds.), Faithful Narratives. The Challenge of Religion in History, usA, Cornell University, 2014, pp. 115-131. 
Mitre, Emilio y Cristina Granada. Las grandes herejías de la Europa cristiana, Madrid, Istmo, 1999 (1983).

Mondragón, Silvina. "Entre Dios y la comunidad. Prácticas y percepciones campesinas en torno a la Iglesia y a la monarquía. Castilla siglos XIV al xvi”, Miscelánea Medieval Murciana, vol. 38, 2014, pp. 147-160.

Moya Sordo, Vera. "El miedo en el escenario del viaje atlántico ibérico, siglos Xv-XvI", Cuadernos de Estudios Gallegos, Lx, núm. 126, enero-diciembre 2013, pp. 225-253.

Muchembled, Robert. Historia del diablo. Siglos XII-XX, México, FCE, 2016 (2000).

Ocańa, Diego de. Viaje por el Nuevo Mundo. De Guadalupe a Potosí, 15991605, ed. crítica, intr. y notas de Blanca López de Mariscal y Abraham Madroñal, con la colaboración de Alejandra Soria. Colección Biblioteca Indiana, 22. Publicaciones del Centro de estudios Indianos (CEI), Universidad de Navarra/Iberoamericana/Vervuert/Bonilla Artigas Editores/ Instituto Tecnológico y de Estudios Superiores de Monterrey, Madrid/ Frankfurt/México, 2010.

Rodríguez, Gerardo. Frontera, cautiverio y devoción mariana, Sevilla, Universidad de Sevilla, 2012.

Roso Díaz, José. "El fraile Jerónimo Diego de Ocaña. Un apunte sobre devoción mariana, arte y literatura en la América hispana del Barroco”, Anuario de Estudios Filológicos, vol. xxxi, 2008, pp. 195-208.

Sigüenza, José. Historia de la Orden de San Jerónimo, est. prel. de Francisco J. Campos y Fernández de Sevilla, Valladolid, Junta de Castilla y León-Consejería de Educación y Cultura, 2000 (1595-1605).

Van Dulmen, Richard. El descubrimiento del individuo, 1500-1800, Madrid, Siglo xxi de España, 2016 (1997).

Williams, Raymond. Sociología de la cultura, Barcelona, Paidós, 1994 (1981).

Wolf, Eric. Figurar el poder. Ideologías de dominación y crisis, México, CIESAs, 2001.

Zumthor, Paul. La medida del mundo. Representación del espacio en la Edad Media, Madrid, Cátedra, 1994. 